\title{
The effect of raw soya bean on in vitro active and passive accumulation by rat small intestine
}

\author{
BY H. O. POPE AND J. R. PATTEN \\ Department of Physiology, The University of Texas Dental Branch, \\ Houston, Texas $77025, U S A$ \\ AND A. L. LAWRENCE \\ Department of Biology, University of Houston, Houston, Texas 77004, USA
}

(Received 3 September 1973-Accepted 8 October 1974)

\begin{abstract}
I. Sections of small intestine from rats given raw-soya-bean(RS) diets had a decreased capacity to actively accumulate $L-m e t h i o n i n e$ when compared to those taken from rats given heated soya bean (HS), and casein-fed controls. The extent of the reduction was small in comparison with pair-fed animals, but was statistically significant in comparison with rats restricted to the same weight gain as the RS group.

2. The differences in the passive uptake of D-mannitol appear to be directly related to differences in gut thickness between the control and RS groups.

3. Values for water movement and intestinal transmural potentials further support the results found in the active accumulation studies.

4. From this study it was concluded that the degree of starvation directly affects the magnitude of the effect of RS diets when comparisons are made against adequately fed controls.
\end{abstract}

Raw soya bean (RS), when used as the main source of dietary protein, induces pancreatic enlargement and growth inhibition in rats (Liener, 1953; Booth, Robbins, Ribelin, DeEds, Smith \& Rackis, r964; Borchers, 1965; Rackis, 1965; Mickelson \& Yang, 1966). Most workers have studied RS by comparison with pair-fed, heatedsoya-bean(HS)-fed control animals. HS is thought to be free from heat-labile substances which have been implicated in producing the adverse effects of RS. There are many known anti-nutritional factors which contribute to the biological toxicity of RS (Mickelson \& Yang, 1966).

Faeces of RS-fed rats have been shown to have a higher sulphur and total nitrogen content than the faeces of rats maintained on HS diets (Kwong, Barnes \& Fiala, 1962). Methionine has been shown to be the rate-limiting amino acid for growth in RS-fed rats (Kwong et al. 1962). Supplementation of RS diets with methionine or cysteine, or both, caused the growth of rats to approach normal rates (Barnes, Fiala \& Kwong, 1962, 1965). These results suggest that RS affects the absorptive process. Thus, the purpose of this experiment was to determine whether absorption in the small intestine of RS-fed rats had been altered.

Classically, methionine has been used to determine the presence of an energydependent carrier system in everted gut sections (Wilson \& Wiseman, 1954). As stated previously, methionine is rate-limiting for growth in RS-fed rats. These facts made methionine the amino acid of choice for the evaluation of the potential effect of RS on the active transport of amino acids. 
Table I. Composition $(\mathrm{g} / \mathrm{kg})$ of diets, containing casein and soya bean as protein sources, given to rats

$\begin{array}{lccc}\text { Protein source } \quad . . & \text { Casein } & \begin{array}{c}\text { Heated } \\ \text { soya bean }\end{array} & \begin{array}{c}\text { Raw } \\ \text { soya bean }\end{array} \\ \text { Raw soya bean* } & - & - & 300 \\ \text { Heated soya bean* } & - & 300 & - \\ \text { Casein† } & 175 & - & - \\ \text { Sucrose } & 498 & 498 & 498 \\ \text { Maize oil } & 90 & 90 & 90 \\ \text { Maize starch } & 125 & 20 & 20 \\ \text { Salt mixture (USP XIV)t } & 50 & 50 & 50 \\ \text { Cellulose } & 80 & 40 & 40 \\ \text { Vitamin mixture\| } & \mathrm{I} & \mathrm{r} & \mathrm{r} \\ \text { Choline chloride } & \mathrm{I} & & \mathrm{r} \\ \text { Digestible energy: } & & 15.34 & 15.34 \\ \quad \text { (MJ/kg) } & 15.97 & 3.67 & 3.67 \\ \text { (Mcal/kg) } & 3.89 & & \end{array}$

* Obtained from Robert Whitney, Central Soya, Chicago, Illinois.

+ 'Vitamin-free'; obtained from Nutritional Biochemical Corp., Cleveland, Ohio.

I USP XIV contained: (A) (g): Cupric sulphate 0.48 , ferric ammonium citrate 94.33 , manganese sulphate $1 \cdot 24$, ammonium alum 0.57 , potassium iodide 0.25 , sodium fluoride $3 \cdot 13 ;(B)(\mathrm{g} / \mathrm{kg})$ : calcium carbonate $68 \cdot 6$, calcium citrate $308 \cdot 3$, calcium diphosphate i I $2 \cdot 8$, magnesium carbonate $35^{\circ} 2$, magnesium sulphate $38 \cdot 3$, potassium chloride $124 \cdot 7$, potassium dihydrogen phosphate $218 \cdot 8$, sodium chloride $77 \cdot 1$, A I62; supplemented with I $g$ zinc carbonate.

$\S$ Obtained from General Biochemicals, Chagrin Falls, Ohio.

If Supplying $(\mathrm{mg} / \mathrm{kg}$ diet): thiamin 50 , riboflavin 80 , pyridoxine 50 , calcium pantothenate 400 , myo-inositol 1000, nicotinic acid 400, pteroylmonoglutamic acid 20, biotin 4 , cyanocobalamin 0.3 , menaphthone 50, $p$-aminobenzoic acid 1000, DL- $\alpha$-tocopheryl acetate 220 , retinol equivalent $4 \cdot 5$, cholecalciferol $0 \cdot I$.

In the previous work done with RS, the pair-fed, HS-fed controls gained significantly more weight over the experimental period. RS-fed rats had subnormal food intakes, therefore both the RS-fed and pair-fed, HS-fed rats were in a state of semistarvation. Semi-starvation is known to increase the uptake of amino acids by rat small intestine (Kershaw, Neame \& Wiseman, 1960; Hindmarsh, Kilby, Ross \& Wiseman, 1967 ; Crampton, Lis \& Matthews, 1970). Therefore, the degree of semistarvation would be expected to affect amino acid uptake. Pair-fed, HS-fed controls gained more weight than RS-fed rats, suggesting a difference in the degree of semistarvation between the two groups. We believed that the pair-fed control group was not entirely adequate for evaluating the effect of RS. A second control group was obtained by further restricting the food intake of the control group so that bodyweight gain equalled the body-weight gain of the RS-fed group. In addition, pair-fed controls were also compared with the RS-fed group.

\section{EXPERIMENTAL}

Animals and diet. Thirty-five male Sprague-Dawley rats having an initial weight of $5^{\circ-60} \mathrm{~g}$ were used in these experiments. These animals were divided into five equal groups and housed individually in wire cages. Three isoenergetic, isonitrogenous diets, each containing $\mathrm{r} 50 \mathrm{~g}$ protein $/ \mathrm{kg}$ derived from RS, HS or casein were used. The composition of each diet is shown in Table $\mathbf{r}$. 
The food intakes for each animal were recorded daily, with body-weights recorded every other day. Those animals whose weight gains or food intakes were significantly different from the other members of their group were removed from the experiment. The animals in one group were fed ad lib., the diet containing $300 \mathrm{~g} \mathrm{RS} / \mathrm{kg}$. Two groups were pair-fed ( $v$. RS-fed group) on diets containing I $70 \mathrm{~g}$ casein and $300 \mathrm{~g} \mathrm{HS} /$ $\mathrm{kg}$ respectively. Two additional groups were fed on diets containing $170 \mathrm{~g}$ casein and $300 \mathrm{~g} \mathrm{HS} / \mathrm{kg}$ respectively, but their food intake was restricted so that the body-weight gain of the animals of each group was the same as the body-weight gain of the RS-fed group. All animals were given water ad lib. throughout the $2 \mathrm{I} \mathrm{d}$ feeding period.

Procedure and analyses. At the end of the $2 \mathrm{I} d$ feeding period, one animal from each group was fasted overnight and killed, by cervical dislocation, the following morning. The small intestine was removed and its total length recorded. A gut section located 80-320 mm proximal to the ileal-caecal junction was removed and gently flushed with $5 \mathrm{ml}$ Krebs-Ringer bicarbonate buffer $\left(\mathrm{pH}_{7} \cdot 4\right)$. The $240 \mathrm{~mm}$ section was then everted and divided into three equal sections. The in vitro everted-sac technique of Wilson \& Wiseman (1954) as modified by Lawrence \& Lawrence (1967) was used with the following exceptions: the initial serosal fluid (fluid bathing the serosal surface of the gut) and mucosal fluid (fluid bathing the mucosal surface of the gut) volumes were O. I $\mathrm{ml}$ and $32 \mathrm{ml}$ respectively. The initial concentration of ${ }_{\mathrm{L}-}-\left[{ }^{14} \mathrm{CH}_{3}\right]$ methionine in both mucosal and serosal fluids was $\mathrm{I} \cdot 05 \times 1 \mathrm{IO}^{-9} \mathrm{~mol} / \mathrm{ml}$, with a specific activity $0.0009 \mu \mathrm{Ci} / \mathrm{ml}$. Initially, the mucosal compartment also contained $3.79 \times 10^{-6} \mathrm{~mol}$ $\mathrm{D}-\left[\mathrm{I}^{-}{ }^{3} \mathrm{H}\right]$ mannitol (specific activity $0.02 \mu \mathrm{Ci} / \mathrm{ml}$ ) $/ \mathrm{ml}$. The incubation temperature was $37^{\circ}$ and the incubation period was $30 \mathrm{~min}$. Throughout the incubation period, the mucosal fluid was gently aerated with $\mathrm{O}_{2}-\mathrm{CO}_{2}(95: 5, \mathrm{v} / \mathrm{v})$. All three gut sections were mounted less than 9 min after the blood supply to the gut was stopped.

After $20 \mathrm{~min}$ of the incubation period, five transmural potential measurements were taken for each section, using the procedure described by Lawrence \& Mailman (1967). Agar electrodes ( $10 \mathrm{~g} / \mathrm{l}$ ), containing I $\mathrm{M}-\mathrm{KCl}$, were placed on each side of the gut section. The opposite ends of the agar electrodes were immersed in a saturated $\mathrm{KCl}$ solution containing glass electrodes. The glass electrodes were in turn connected to a $\mathrm{pH}$ meter (digital model no. I12; Corning Scientific Instruments, Medfield, Mass., USA) to measure the transmural potentials. The mean of five consecutive transmural potential measurements was taken as the transmural potential for the gut section.

Simultaneously with the mounting procedure, the rat pancreas was excised and weighed. Also, the remaining small intestine (minus the $240 \mathrm{~mm}$ section removed for the in vitro study) was flushed thoroughly with buffer and dried to a constant weight at $98^{\circ}$ for $2 \mathrm{~d}$.

Transport determinations. At the end of the $30 \mathrm{~min}$ incubation period, the mounting apparatus with the attached everted sac was removed from the mucosal fluid. The serosal fluid was immediately evacuated and the final serosal fluid volume was determined by weighing. Samples (гоо $\mu 1$ ) from the serosal and mucosal fluids were added to $15 \mathrm{ml}$ scintillation fluid. The scintillation fluid contained: 31 toluene, $252 \mathrm{ml} \mathrm{Bio-Solv}{ }^{\mathrm{TM}}$ (Beckman Instruments Inc., Fullerton, Cal., USA), $96 \mathrm{ml}$ 
Permafluor ${ }^{\text {TM }}$ (Packard Instrument Co. Inc., Downers Grove, Ill., USA). In addition, a Io $\mu 1$ sample from the serosal fluid was immediately applied to Whatman No. I filter paper. Ascending, one-dimensional chromatography was used with a solvent system of $n$-butanol-acetic acid-water (4:I:I, by vol.). Ninhydrin spray ( $\mathrm{g} / \mathrm{l})$ was used to detect the spots. The ninhydrin-positive spots were removed and placed in I $5 \mathrm{ml}$ scintillation fluid to determine the amount of ${ }^{14} \mathrm{C}$-labelled L-methionine. The chromatographic analysis indicated that at least $90 \%$ of the L-methionine present in the serosal fluid was chemically unaltered.

Immediately after the serosal fluid was evacuated, the gut was removed from the mounting apparatus, dissected longitudinally and rinsed in ethanol $(700 \mathrm{ml} / \mathrm{l})$. After blotting, the section was weighed and placed in $7 \mathrm{ml}$ ethanol $(700 \mathrm{ml} / \mathrm{l})$ for $3 \mathrm{~d}$. It was determined previously that a $3 \mathrm{~d}$ extraction in ethanol removed more than $90 \%$ of the ethanol-soluble fraction containing the labelled compounds. After $3 \mathrm{~d}$, a I $\mathrm{ml}$ sample of the ethanol-soluble extract was added to $15 \mathrm{ml}$ scintillation fluid to determine the amount of radioactivity in the extract.

After ethanol extraction the section was divided in half. One half was placed in I $\mathrm{ml}$ of a solubilizer (Soluene ${ }^{\mathrm{TM}}$ IOO, Packard Instrument Co. Inc.) and, after complete digestion of the gut tissue, $15 \mathrm{ml}$ scintillation fluid was added. This procedure was used to determine the amount of radioactivity present in the ethanol-insoluble portion of the section. It was assumed that this ethanol-insoluble accumulation value represented the amount of $\mathrm{L}$-methionine incorporated into the gut tissue by anabolism. The other half was dried to constant weight in an oven set at $98^{\circ}$.

The radioactivity of the samples was determined using a Packard Tri-Carb liquid scintillation spectrophotometer model 3365 (Packard Instrument Co. Inc.) with an automatic counting control (model 574) for the external standard.

Statistical analysis. Computer programmes were developed to analyse the active and passive data. Mean values and standard errors of the mean were also computed and Student's $t$ test was used to analyse the grouped data.

\section{RESULTS}

The effects of diet on the pancreas, gut and body-weights. The influence of HS, casein and RS diets on the pancreas, gut and body-weights is shown in Table 2. Since the body-weights of the animals varied, the gut and pancreas weights were expressed as $\mathrm{g} / \mathrm{kg}$ body-weight. An estimate of gut thickness was obtained by expressing gut weight (dry) per unit length of intestine.

Animals given the RS diet had a significantly higher pancreas weight than either of the pair-fed control groups, and also had a significantly lower body-weight gain than the pair-fed controls. These results are typical of the known effects of RS on the rat (Liener, 1953; Booth et al. 1964; Borchers, 1965; Rackis, I965; Mickelson \& Yang, 1966).

The pancreas weight of controls on a restricted intake was much lower than that of the pair-fed groups (Table 2), and that of the RS-fed group was significantly higher than the respective values for either the restricted-intake, casein- or HS-fed groups. 
Table 2. The effects of heated-soya-bean, raw-soya-bean and casein diets on the pancreas, gut and body-weights of rats pair-fed or given restricted access to these diets

(Mean values with their standard errors; no. of animals in parentheses)

\begin{tabular}{|c|c|c|c|c|c|c|c|c|c|c|}
\hline \multirow{4}{*}{$\begin{array}{l}\text { Feeding regimen } \\
\text { Protein source }\end{array}$} & \multicolumn{10}{|c|}{ Dietary treatment* } \\
\hline & \multirow{2}{*}{\multicolumn{2}{|c|}{$\begin{array}{l}\text { Pair-fed } \\
\text { Casein (6) }\end{array}$}} & \multirow{2}{*}{\multicolumn{2}{|c|}{$\begin{array}{c}\text { Pair-fed } \\
\text { Heated } \\
\text { soya bean (4) }\end{array}$}} & \multirow{2}{*}{\multicolumn{2}{|c|}{$\begin{array}{c}\text { Ad lib. } \\
\text { Raw } \\
\text { soya bean (6) }\end{array}$}} & \multicolumn{4}{|c|}{ Restricted intake } \\
\hline & & & & & & & \multicolumn{2}{|c|}{ Casein (3) } & \multicolumn{2}{|c|}{$\begin{array}{l}\text { Heated } \\
\text { soya bean (5) }\end{array}$} \\
\hline & Mean & $\mathrm{SE}$ & Mean & $\mathrm{SE}$ & Mean & $\mathrm{SE}$ & Mean & $\mathrm{SE}$ & Mean & SE \\
\hline $\begin{array}{l}\text { Pancreas weight } \\
\text { (g/kg body-wt) } \\
\text { Gut weight (dry) }\end{array}$ & $7^{7 \cdot 8^{a}}$ & 0.3 & $7 \cdot 7^{\mathrm{a}}$ & 0.4 & 10.4 & 0.5 & $6 \cdot 9^{\mathrm{a}}$ & 0.6 & $6 \cdot 5^{a}$ & 0.5 \\
\hline $\begin{array}{l}\text { (g/kg body-wt) } \\
\text { Total gut length }\end{array}$ & $8 \cdot 0^{b}$ & 0.2 & $8 \cdot 3$ & 0.3 & $8 \cdot 4$ & 0.2 & $7 \cdot 0^{a}$ & $0 \cdot 3$ & $8 \cdot 2$ & 0.2 \\
\hline $\begin{array}{l}\text { (mm/kg body-wt) } \\
\text { Gut weight (dry) }\end{array}$ & $6840^{a, b}$ & 210 & $784^{\circ}$ & 420 & 8660 & 290 & 92220 & $44^{\circ}$ & 9020 & 440 \\
\hline $\begin{array}{l}\text { (mg/mm gut length) } \\
\text { Body-weight gain (\%) } \\
\text { Food intake }(\mathrm{g} / \mathrm{d})\end{array}$ & $\begin{array}{l}1 \cdot 176^{\mathrm{a}, \mathrm{b}} \\
51 \cdot 0^{\mathrm{a}, \mathrm{b}} \\
8 \cdot 9\end{array}$ & $\begin{array}{l}0.039 \\
2 \cdot 0\end{array}$ & $\begin{array}{c}1 \cdot 059 \\
46 \cdot 7^{\mathrm{a}, \mathrm{c}} \\
8 \cdot 9\end{array}$ & $\begin{array}{l}0.027 \\
2 \cdot 3\end{array}$ & $\begin{array}{l}0 \cdot 970 \\
36 \cdot 6 \\
8 \cdot 9\end{array}$ & $\begin{array}{l}0.038 \\
0.7\end{array}$ & $\begin{array}{l}0.763^{a, c} \\
35 \cdot 5 \\
6 \cdot 2\end{array}$ & $\begin{array}{l}0.033 \\
1.8\end{array}$ & $\begin{array}{l}0.911 \\
35.9 \\
6.6\end{array}$ & $\begin{array}{l}0.026 \\
1.4\end{array}$ \\
\hline
\end{tabular}

a Significantly different from the raw-soya-bean-fed group $(P<0.05)$.

b Significantly different from the restricted-intake, casein-fed group $(P<0.05)$.

c Significantly different from the restricted-intake, heated-soya-bean-fed group $(P<0.05)$.

* For details of diets and treatments, see Table I and p. II9.

In fact, the pancreas weight of the RS-fed group was $26 \%$ higher than that of the pair-fed groups and $36 \%$ higher than that of the groups on a restricted intake.

Included in Table 2 are measurements of dry gut weight and gut length for the five dietary groups. There were no significant differences in the gut weights except in the instance of the restricted-intake, casein-fed group. With respect to gut length, there were no significant differences between the RS-fed group and the controls on restricted intakes. However, the total gut length of the pair-fed, casein-fed group was significantly less $(P<0.05)$ than that of the RS-fed or the restricted-intake controls. When expressed per unit length of intestine, values obtained for the gut dry weight indicated that the pair-fed animals had thicker intestines than the RS-fed or restrictedintake groups. The guts of RS-fed and restricted, HS-fed animals were of similar thickness, but the restricted-intake, casein-fed group had significantly thinner guts than the other four groups. These results suggested that the gut of the RS-fed group and restricted-intake controls was thinner than that of the pair-fed groups.

The effects of diet on the passive accumulation of ${ }^{3} \mathrm{H}$-labelled mannitol. The influence of HS, casein and RS diets on the passive accumulation of $\mathrm{D}-\left[{ }^{3} \mathrm{H}\right]$ mannitol is shown in Table 3. The effect of RS on passive accumulation was essentially similar to that of RS on pancreas weight (Table 2); i.e. the greatest difference was between values for RS-fed rats and restricted-intake controls. All values for passive accumulation for the restricted-intake, casein-fed group were significantly higher $(P<0.05)$ than those for the RS-fed group, and the values for the restricted-intake, HS-fed group were significantly different only from those of the RS-fed group.

It is also of interest to compare the pair-fed and restricted-intake, casein-fed groups. 
Table 3. The effects of heated-soya-bean, raw-soya-bean and casein diets on the passive accumulation ( $\mu \mathrm{mol} / \mathrm{g} d r y$ wt) of D-mannitol and total fluid movement ( $\mathrm{ml} / \mathrm{g}$ dry wt) in the intestine of rats pair-fed or given restricted access to these diets

(Mean values with their standard errors; no. of determinations in parentheses)

\begin{tabular}{|c|c|c|c|c|c|c|c|c|c|c|c|}
\hline \multirow{4}{*}{$\begin{array}{l}\text { Feeding regimen } \\
\text { Protein source }\end{array}$} & \multirow{4}{*}{$\begin{array}{l}\cdots \\
\cdots\end{array}$} & \multicolumn{10}{|c|}{ Dietary treatment* } \\
\hline & & \multicolumn{2}{|c|}{ Pair-fed } & \multicolumn{2}{|c|}{ Pair-fed } & \multicolumn{2}{|c|}{ Ad lib. } & \multicolumn{4}{|c|}{ Restricted intake } \\
\hline & & \multicolumn{2}{|c|}{ Casein (I6) } & \multicolumn{2}{|c|}{$\begin{array}{c}\text { Heated } \\
\text { soya bean (II) }\end{array}$} & \multicolumn{2}{|c|}{$\begin{array}{c}\text { Raw } \\
\text { soya bean (17) }\end{array}$} & \multicolumn{2}{|c|}{ Casein (8) } & \multicolumn{2}{|c|}{$\begin{array}{c}\text { Heated } \\
\text { soya bean (14) }\end{array}$} \\
\hline & & Mean & $\mathrm{SE}$ & Mean & $\mathrm{SE}$ & Mean & SE & Mean & SE & Mean & $\mathrm{SE}$ \\
\hline \multirow{2}{*}{\multicolumn{2}{|c|}{$\begin{array}{l}\text { Serosal accumulati } \\
\text { Ethanol-soluble } \\
\text { accumulation } \dagger\end{array}$}} & $1 \cdot 32^{b}$ & O.II & I.44 & 0.14 & $I \cdot 49$ & 0.19 & $2 \cdot 35^{\mathrm{a}, \mathrm{c}}$ & 0.24 & $\mathrm{I} \cdot 66$ & 0.15 \\
\hline & & $x \cdot 79^{b}$ & 0.09 & $x \cdot 84$ & 0.17 & $I \cdot 65$ & 0.12 & $2 \cdot 59^{\mathrm{a} \cdot \mathrm{c}}$ & 0.34 & $I \cdot 95$ & 0.11 \\
\hline \multirow{2}{*}{\multicolumn{2}{|c|}{ Total accumulation }} & & & - & & - & & - & & 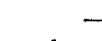 & \\
\hline & & $3.08^{b}$ & $\begin{array}{ll}-1 \\
0.13 \\
0.08\end{array}$ & $\begin{array}{l}3 \cdot 28 \\
\cdot \cdot 6 \mathrm{a}, \mathrm{c}\end{array}$ & 0.19 & 3.14 & 0.21 & $4 \cdot 93^{a, c}$ & 0.42 & $3 \cdot 61$ & 0.13 \\
\hline \multicolumn{2}{|c|}{ Total fluid movement } & $I \cdot O I^{d} \cdot 0$ & 0.08 & $I \cdot I b^{a, C}$ & 0.09 & 0.71 & 0.12 & $I \cdot 44^{\mathrm{a}}$ & 0.15 & $I \cdot 54^{\mathrm{a}}$ & 0.10 \\
\hline
\end{tabular}

a Significantly different from the raw-soya-bean-fed group $(P<0.05)$.

b Significantly different from the restricted-intake, casein-fed group $(P<0.05)$.

c Significantly different from the restricted-intake, heated-soya-bean-fed group $(P<0.05)$.

* For details of diets and treatments, see Table I and p. I I 9 .

$\dagger$ For definition of terms, see p. 120.

Table 4. The effects of heated-soya-bean, raw-soya-bean and casein diets on intestinal transmural potentials $(\mathrm{mV})$ and active accumulation ( $\mu \mathrm{mol} / \mathrm{g}$ dry wt) of L-methionine by rats pair-fed or given restricted access to these diets

Mean values with their standard errors; no. of determinations in parentheses)

Dietary treatment*

\begin{tabular}{|c|c|c|c|c|c|c|c|c|c|c|c|}
\hline \multirow{3}{*}{$\begin{array}{l}\text { Feeding regimen } \\
\text { Protein source }\end{array}$} & \multirow{3}{*}{$\begin{array}{l}\cdots \\
\cdots\end{array}$} & \multicolumn{2}{|c|}{ Pair-fed } & \multicolumn{2}{|c|}{ Pair-fed } & \multicolumn{2}{|c|}{ Ad lib. } & \multicolumn{4}{|c|}{ Restricted intake } \\
\hline & & \multicolumn{2}{|c|}{ Casein (I6) } & \multicolumn{2}{|c|}{$\begin{array}{c}\text { Heated } \\
\text { soya bean (II) }\end{array}$} & \multicolumn{2}{|c|}{ soya bean (I $\underbrace{\text { Raw }}$} & \multicolumn{2}{|c|}{ Casein (8) } & \multicolumn{2}{|c|}{$\begin{array}{c}\text { Heated } \\
\text { soya bean (14) }\end{array}$} \\
\hline & & Mean & $\mathrm{SE}$ & Mean & $\mathrm{SE}$ & Mean & $\mathrm{SE}$ & Mean & SE & Mean & SE \\
\hline \multirow{2}{*}{\multicolumn{2}{|c|}{$\begin{array}{l}\text { Serosal accumulation } \uparrow \\
\text { Ethanol-soluble } \\
\text { accumulationt } \\
\text { Ethanol-insoluble }\end{array}$}} & $6 \cdot 22^{b} \cdot c$ & 0.55 & $8 \cdot 07$ & 0.57 & $6 \cdot 45$ & 0.76 & I $370^{a}$ & $2 \cdot 30$ & $9 \cdot 63^{a}$ & 0.92 \\
\hline & & $20 \cdot 13^{b}$ & $1 \cdot 62$ & $23 \cdot 94$ & $I \cdot 62$ & $20 \cdot 12$ & I.38 & $27 \cdot 65^{a}$ & $2 \cdot 84$ & 26.99 & $3 \cdot 5^{8}$ \\
\hline \multicolumn{2}{|l|}{$\begin{array}{l}\text { Ethanom-insolubie } \\
\text { accumulation } \uparrow\end{array}$} & $19 \cdot 67$ & $2 \cdot 83$ & $22 \cdot 80$ & 3.40 & $16 \cdot 23$ & $2 \cdot 15$ & $25 \cdot 87^{a}$ & 4.99 & $30 \cdot 55^{\mathrm{a}}$ & $6 \cdot 38$ \\
\hline \multicolumn{2}{|c|}{ Tissue accumulation $†$} & $39 \cdot 80$ & $4 \cdot 13$ & $46 \cdot 20$ & $4 \cdot 72$ & $36 \cdot 35$ & 3.09 & $53 \cdot 5^{\mathrm{I}}$ & $7 \cdot 23$ & $57 \cdot 54^{\mathrm{a}}$ & $9 \cdot 78$ \\
\hline \multirow{2}{*}{\multicolumn{2}{|c|}{$\begin{array}{l}\text { Total accumulation } \\
\text { Transmural potentials }\end{array}$}} & $46 \cdot 02^{b}$ & $4 \cdot 36$ & $54 \cdot 27$ & 477 & $42 \cdot 80$ & 3.38 & $67 \cdot 22^{a}$ & 9.05 & $67 \cdot 16^{a}$ & 10.15 \\
\hline & & $7 \cdot 2$ & 0.5 & $7 \cdot 3$ & 0.8 & $6 \cdot 1$ & 0.4 & $8 \cdot 2^{a}$ & 0.8 & $7 \cdot 7^{\mathrm{a}}$ & 0.4 \\
\hline
\end{tabular}

a Significantly different from the raw-soya-bean-fed group $(P<0.05)$.

b Significantly different from the restricted-intake, casein-fed group $(P<0.05)$.

c Significantly different from the pair-fed, heated-soya-bean-fed group $(P<0.05)$.

* For details of diets and treatments, see Table I and p. I I 9 .

+ For definition of terms, see p. Izo. 
The animals given restricted access to the casein diet had significantly higher accumulation values than the pair-fed animals given the casein diet. Interestingly enough, there were no significant differences between the pair-fed and restricted-intake, HS-fed groups. Furthermore, passive accumulation of D-mannitol in the restrictedintake, casein-fed group was significantly greater than that of the restricted-intake, HS-fed group. In contrast, there were no significant differences between the pair-fed controls.

The pair-fed controls were found to have a significantly greater $(P<0.05)$ fluid movement than the RS-fed group. The restricted-intake controls had a greater $(P<0.05)$ capacity to accumulate fluid than the RS-fed group. The restricted-intake controls had greater $(P<0.05)$ rates of fluid movement than the pair-fed controls.

The effect of diet on the active transport of ${ }^{14} \mathrm{C}$-labelled methionine. The effects of $\mathrm{HS}$, casein and RS diets on the active transport of L- $\left[{ }^{14} \mathrm{CH}_{3}\right]$ methionine and the transmural potentials are shown in Table 4. The general pattern was the same as that shown by the results in Tables 2 and 3 . The effect of RS on amino acid transport was more apparent when the RS group was compared with the restricted-intake controls; all accumulation (transport) values for the restricted-intake controls were greater (nine of ten values, $P<0.05$ ) than those of the RS-fed group. Eight of ten accumulation values for the pair-fed controls were greater (though not significantly so) than those for the RS-fed group. These results suggested that the RS-fed animals had a reduced capacity to actively accumulate L-methionine.

The same general pattern was shown by the values for transmural potentials. The restricted-intake controls had significantly higher $(P<0.05)$ transmural potentials than the RS-fed group. The pair-fed controls had higher transmural potentials, but these values were not significantly different from those of the RS-fed group. These results suggested that there was less ionic transport in the RS-fed group than in the controls.

\section{DISCUSSION}

The everted-sac technique was used in this study to determine both passive and active accumulation of small organic compounds. As D-mannitol is not actively transported by animals (Miller \& Schedl, 1970) it was used in the determination of passive accumulation. Variations in the thickness of the diffusion barrier (gut) would be expected to affect passive uptake. By expressing total gut weight per mm gut length, an estimate of over-all gut thickness was obtained. The differences in gut thickness betweent he control groups may possibly explain part, or all of the variations seen in passive accumulation. Other factors (e.g. surface area, diffusion coefficient) in addition to gut thickness may have been involved in the variations of passive accumulation seen in this study. It has been noted that protein deprivation decreases surface area and surface enzyme content of the small intestine (Hill, Prosper, Hirschfield \& Kern, 1968; Kumar \& Chase, 1971).

The rate of active transport of L-methionine for all four control groups was higher than that for the RS-fed group, with the largest difference found between the restricted-intake animals and the RS-fed animals. This decrease in active uptake 
against an apparent concentration gradient cannot be explained by a decreased passive uptake in the same animal. For example, taking into consideration the experimental design (i.e. initially equal serosal and mucosal L-methionine concentrations and a greater amount of L-methionine in the serosal compartment at the end of each experiment), a decreased passive uptake would result in a decreased net flux of the amino acid into the mucosal compartment by passive means. The suggested decrease in passive permeability in the RS-fed group compared with that in the restricted-intake controls would produce serosal accumulation values for $\mathrm{L}$-methionine which were higher rather than lower. Thus, in all probability, active transport was depressed more by the RS diet than the values indicated. In addition, changes in the rate of passive accumulation were not large enough to account for the changes seen in the rates of active accumulation. For example, an initial ambient concentration of $\mathrm{I} \cdot 05 \mathrm{nmol}$ methionine/ml suggests that the maximum passive accumulation into the tissue is $0.75 \mathrm{nmol} / \mathrm{g}$ dry weight (assuming the water content of the gut is $750 \mathrm{mg} / \mathrm{g}$ and the passive accumulation of L-methionine is not greater than that of D-mannitol). The net passive accumulation of $\mathrm{L}$-methionine into the serosal compartment was zero in this study. Thus, the maximum passive accumulation of $0.75 \mathrm{nmol} \mathrm{L}-m e t h i o n i n e / \mathrm{g}$ dry weight cannot account for the minimum difference of $14 \mathrm{nmol} / \mathrm{g}$ dry weight obtained when total active accumulation of the RS-fed group is compared with that of the restricted-intake controls.

The reduced active transport of L-methionine might possibly explain previous reports that methionine supplementation increased growth rates of RS-fed rats to approach levels found in control rats (Barnes et al. 1962, 1965). What then is the mode of action of RS on the small intestine of the rat? The reduced active accumulation of L-methionine by the RS-fed rats could be due to either a decrease in the affinity of the carrier for the amino acid or a decrease in the number of carriers, since the RS-fed animals accumulated less L-methionine than the four control groups, using an initial ambient concentration in first-order kinetics. Further, the amount of water movement and the transmural potentials of the RS-fed group were smaller than those of the four control groups. Once again, the largest difference was found between the RS-fed group and the restricted-intake control groups. Transmural potentials are associated with the movement of charged particles across the gut; in turn water movement closely parallels sodium transport. Non-electrolytes such as amino acids have been shown to be transported in association with ions and to cause an increase in transmural potential (Edmunds, 197I). The smaller transmural potentials of the RS-fed animals could be caused by a direct effect of RS on the amino acid carrier. However, it is possible that RS directly decreases the active movement of ions, which in turn could explain the reduced water movement, transmural potential and L-methionine transport seen in the RS group as compared with the control groups.

Throughout this study results for the restricted-intake control groups further accentuate the differences found between the RS-fed group and the pair-fed control groups. The enlargement of the pancreas and growth depression of RS-fed rats is well documented. However, to our knowledge no one has compared the RS effect with a control group similar to the restricted-intake groups used in this study. 
Further, since the active-transport mechanisms of the rat small intestine were shown to be impaired, one would expect to see signs of nutritional deficiencies in RS-fed rats. In this respect, RS-fed animals have been shown to have increased nutritional requirements (Davis, Norris \& Kratzer, I962; Barnes et al. 1965; Miller, Ullrey, Zutaut, Hoefer \& Luecke, I965; Edelstein \& Guggenheim, I969).

This work suggests the need for more adequate controls when the effects of RS are being studied. The results presented in this paper have extended the anti-nutritional effects of RS on the gut, in terms of active uptake. Further, the problem of semistarvation has been implicated as playing a major part in the dietary effects of RS.

\section{REFERENCES}

Barnes, R. H., Fiala, G. \& Kwong, E. (1962). J. Nutr. 77, 278.

Barnes, R. H., Fiala, G. \& Kwong, E. (1965). F. Nutr. 85, 127.

Booth, A. N., Robbins, D. J., Ribelin, W. E., DeEds, F., Smith, A. K. \& Rackis, J. J. (I964). Proc. Soc. exp. Biol. Med. I16, I067.

Borchers, R. (1965). Fedn Proc. Fedn Am. Socs exp. Biol. 24, I494.

Crampton, R. F., Lis, M. T. \& Matthews, D. M. (1970). F. Physiol., Lond. 207, 66 P.

Davis, P. N., Norris, L. C. \& Kratzer, F. H. (1962). \%. Nutr. 77, 217.

Edelstein, S. \& Guggenheim, K. (1969). Israel f. med. Sci. 5, 415.

Edmunds, C. J. (1971). Proc. R. Soc. Med. 64, 1023.

Hill, R. B. Jr, Prosper, J., Hirschfield, J. S. \& Kern, F. Jr (1968). Expl Mol. Path. 8, 66.

Hindmarsh, J. T., Kilby, D., Ross, B. \& Wiseman, G. (I967). F. Physiol., Lond. 188, 207.

Kershaw, T. G., Neame, K. D. \& Wiseman, G. (1960). F. Physiol., Lond. 152, 182.

Kumar, V. \& Chase, H. P. (I97r). F. Nutr. ror, I 509.

Kwong, E., Barnes, R. H. \& Fiala, G. (1962). f. Nutr. 77, 312.

Lawrence, A. L. \& Lawrence, D. C. (1967). Comp. Biochem. Physiol. 22, 341.

Lawrence, A. L. \& Mailman, D. S. (1967). F. Physiol., Lond. 193, 535.

Liener, I. E. (1953). F. Nutr. 49, 527.

Mickelson, O. \& Yang, M. A. (1966). Fedn Proc. Fedn Am. Socs exp. Biol. 25, I04.

Miller, D. L. \& Schedl, H. P. (1970). Gastroenterology 58, 40.

Miller, E. R., Ullrey, D. E., Zutaut, C. L., Hoefer, J. A. \& Luecke, R. L. ( r 965). F. Nutr. 85, 347.

Rackis, J. J. (1965). Fedn Proc. Fedn Am. Socs exp. Biol. 24, 1488.

Wilson, T. H. \& Wiseman, G. (1954). F. Physiol., Lond. 123, 26. 